\title{
STUDENTS EVALUATE EDUCATIONAL PSYCHOLOGY TEXTS
}

\author{
RAY H. SIMPSON \\ University of Illinois \\ and \\ W. R. DIXON, JR. \\ University of Michigan
}

ON the basis of what criteria should texts for a particular class be selected? This is a question which periodically faces almost every teacher. Even in those situations where texts are selected by an administrator or textbook committee the teacher still has a considerable stake in how the selection is made.

A question closely related to the one posed in the preceding paragraph is this: Whose judgments should be considered when decisions are made regarding what text(s) or other resources shall be used? In answering this question there are probably three major alternatives plus possible combinations of these major alternatives. First, texts or other resources may be selected by an individual or group of individuals not directly involved in the teaching-learning situation in which the resources are to be used. Such an individual might be a department head, a principal or superintendent, or someone other than the teacher. The committee may be composed of teachers, administrators, or some combination of these. Second, decisions about texts and other resources may be made almost exclusively by the teacher of the particular class involved. Third, the reactions and judgments of the students who use the texts or other resources may be considered of primary importance in their selection. And finally, of course, the teacher may use his own individual judgment into which he has consciously tried to weigh and incorporate the reactions of students and other teachers.

The procedures and results here reported rest on the assumption that the reactions of learners to texts and other resources 
they are expected to use are factors of sufficient significance to the teacher to justify determining what such reactions are. It is suggested that the procedures here described, or adaptations of them, can be profitably used by teachers in most fields to get, in a systematic fashion, student points of view which will stimulate interest, and more desirable learning, through the selection of more appropriate resources.

\section{Purpose of Experiment}

This experiment, then, has as its major purposes (a) the demonstration of a procedure by which teachers, particularly high-school and college teachers, can systematically obtain the reactions of learners to the resources which they are using, and (b) the presentation of actual results of learner ratings of twelve texts used in three graduate classes of Advanced Educational Psychology taught during the Summer Session of I949 at the University of Illinois.

\section{The Experimental Classes}

Two of the three classes of Advanced Educational Psychology were taught by one of the writers. These classes will be labeled $A$ and $B$. The third course was taught by the other writer and will be referred to as Class $C$. Since it is quite possible that the instructor and his teaching procedure may have had some effect upon the evaluation of resources, results of ratings will be reported separately by instructors.

Practically all of the students had had teaching experience. Early in the course each student was asked to indicate the area of his major interest. Table I gives a picture of the composition of the classes through a summary of these interests.

\section{Texts Available}

Before the classes started the instructors jointly considered some eighteen texts which they thought might be of value to students of educational psychology. Out of this initial group of texts twelve were selected as ones which the instructors felt might be most useful in the course. Such factors as the following were given weight in this initial selection of twelve 
texts: What had been the reactions of past students to this text or a similar one? Did this text represent a somewhat different approach to the psychology of teaching-learning situations?

TABLE $\mathbf{I}$

Major Areas of Interest of Students in Three Adoanced Educational Psychology Classes

\begin{tabular}{|c|c|c|c|c|}
\hline Interest Area & Class & Class & $\underset{\mathrm{C}}{\text { Class }}$ & $\begin{array}{c}\text { All } \\
\text { Classes }\end{array}$ \\
\hline 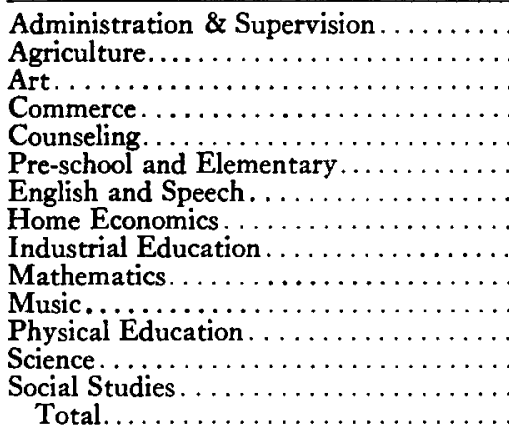 & $\begin{array}{r}9 \\
\\
3 \\
2 \\
1 \\
13 \\
13 \\
8 \\
1 \\
1 \\
1 \\
5 \\
1 \\
6 \\
6 \\
4 \\
2 \\
56\end{array}$ & $\begin{array}{r}12 \\
2 \\
8 \\
1 \\
7 \\
2 \\
1 \\
3 \\
3 \\
1 \\
7 \\
7 \\
4 \\
58\end{array}$ & $\begin{array}{r}5 \\
1 \\
7 \\
8 \\
4 \\
3 \\
3 \\
2 \\
1 \\
15 \\
2 \\
6 \\
57\end{array}$ & $\begin{array}{r}26 \\
2 \\
4 \\
17 \\
2 \\
28 \\
14 \\
5 \\
7 \\
10 \\
3 \\
28 \\
13 \\
12 \\
171\end{array}$ \\
\hline
\end{tabular}

The twelve texts selected for recommendation to the students, together with the two short paragraphs which preceded their listing on a mimeographed sheet, are indicated below.

One principle to keep in mind in getting and using resources (in this case texts) is that those resources which are very appropriate for one learner in a class may be most inappropriate for another learner in the same class. Some contributing factors to this principle are individual differences in needs, attitudes, skills, and basic abilities, and in what is considered usable material.

In line with the principle stated in the preceding paragraph each student is asked to acquire one of the texts from List I and one of the texts from List II below. It is not necessary to acquire either text till after the class meets.

\section{LIST I}

I. Crow and Crow

2. Davis, R. A.

3. Gates et al

4. Pressey and Robinson
Educational Psychology, American Book Co., 1948.

Educational Psychology, McGrawHill, I 948.

Educational Psychology, Macmillan, 1948 .

Psychology and the New Education, Harpers, I944. 
5. Skinner, C. E. (Ed.) Educational Psychology, Prentice

6. Sorenson, $\mathrm{H}$. Hall, 1945 . Psychology in Education, McGrawHill, 1948.

\section{LIST II}

7. Hilgard, E. R.

8. McGeogh, J. A.

9. Mursell, J. L.

Io. Snygg and Combs

I I. Tuttle, H. S.

I2. Woodruff, A. D.

Theories of Learning, AppletonCentury, 1948.

The Psychology of Human Learning, Longmans, Green, I 945.

Successful Teaching, McGraw-Hill, 1946.

Individual Behavior, Harpers, I949.

Dynamic Psychology and Conduct, Harpers, I 949.

Psychology of Teaching, Longmans, I948.

\section{Use of Texts in Classes}

Since the purposes for which texts are used are important in their evaluation, a brief description of such purposes will be given.

In Classes $\mathrm{A}$ and $\mathrm{B}$, students were encouraged to consider using the texts for, at least, the following purposes:

I. To learn how to get help from educational psychology resources in identifying and attacking professional problems which are significant to them in their fields. Achieving this purpose will involve intensive study of selected parts of several texts.

2. To learn the types of help which can be got from educational psychology resources. Work in connection with this purpose will involve making extensive use of educational psychology tables of contents, chapter summaries, and other key parts of the books.

3. To practice systematic evaluation of resources.

In these two classes most of the out-of-class work of each student was related to (a) the systematic identification of professional problems he had faced or appeared likely to face and (b) the development and critical analysis of possible solutions to these problems.

Thus, in Classes $A$ and $B$ an attempt was made to have learner-professional problems form the framework of his study and thinking, and psychological resources were used liberally 
to aid in identifying and solving such problems. It will be noted that in these two classes the conventional pattern of the study of texts for test purposes was not emphasized.

In Class $\mathrm{C}$ the texts were used for two purposes: (I) as reading material to complement the class discussions and lectures in the areas of child development, adjustment, learning, and evaluation; (2) as reference material for the individual problems each student worked on. It is felt that equal emphasis was placed on each of these purposes. For, while all of the examinations were pointed at the material presented in the lectures, discussions, and films, the students also knew that the records they turned in on their individual problems were of equal importance as far as grades and professional growth were concerned.

\section{Evaluating the Texts}

In all three classes each student was encouraged to use a minimum of two books from one list and three from the other list. All books were readily available through exchange between students within the class. Each student, with a few exceptions, used and evaluated during the term the two books he had purchased plus a minimum of three other books which he borrowed in most cases from other students in his class.

As an aid to useful evaluation of texts each student in Classes $A$ and $B$ did the following: (a) listed criteria he thought should be considered in evaluating the worth of a text resource in Advanced Educational Psychology, (b) shared his thinking about criteria with his subgroup within the class and helped the subgroup to set up criteria which those in the group thought helpful, and (c) listed for each text he evaluated what he considered to be its strong points and what he considered to be its weak points. In doing part (c) most students made much use of the thinking that had resulted from step (b). In addition, in parts of several class periods problems related to the evaluation of these texts and other resources were discussed, and in all steps an attempt was made by the instructor to give as much guidance as feasible.

In Class $\mathrm{C}$ the problem of evaluating the various texts was taken up at several of the early class meetings. Various uses of 
texts were discussed and the purposes which have already been mentioned in this report were adopted as legitimate uses of texts in the field of educational psychology. It was recommended that a record be kept of the desirable and undesirable features of the books used. From time to time these were discussed by the group.

In all classes students knew from the beginning of the course that, as a part of their work, they would be asked to evaluate the books by the end of the term.

At the time each student used a text he was asked to make a tentative rating of the text on a nine-point scale with " 9 " the best possible rating and " $I$ " the poorest possible rating.

One week before the end of the course each student was asked to evaluate, using the nine-point scale, each book he had used on these two bases:

(I) What is your general rating of the book as an aid in giving you a better understanding of the problems and principles of educational psychology?

(2) What is your rating of the book based on the actual help you got on the professional problems you attacked this term?

Results from question (I) will be called general evaluation and results from question (2) will be labeled evaluation of help on problems.

\section{Result of Evaluations}

In Table 2 is presented a summary of the ratings given in answer to the first question raised: What is your general rating of the book as an aid in giving you a better understanding of problems and principles of educational psychology?

An analysis of the variance of the ratings which produced the results shown in Table 2 may be summarized here.

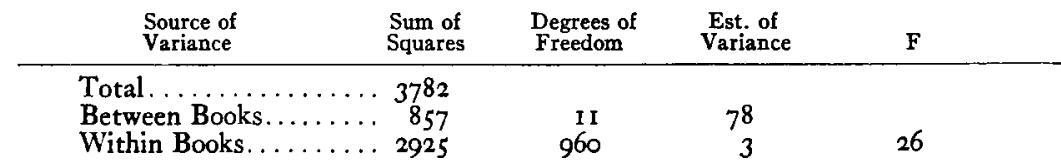

These data would indicate the mean ratings for books differed quite significantly. An F of 2.26 is significant at the I per cent level. 
TABLE 2

General Evaluation of Texts by all Classes

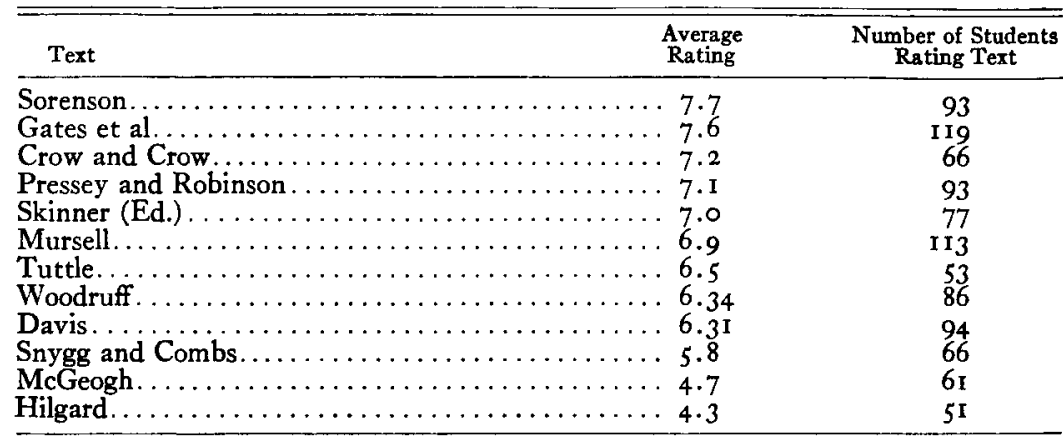

TABLE 3

General Evaluation of Texts in Classes $A$ and $B$

\begin{tabular}{|c|c|c|c|c|c|c|c|c|c|c|c|}
\hline Text & $\begin{array}{c}\text { Average } \\
\text { Rating }\end{array}$ & $\begin{array}{c}\text { Low } \\
1\end{array}$ & $\begin{array}{l}N_{L} \\
2\end{array}$ & $\begin{array}{c}\mathrm{mbe} \\
3\end{array}$ & $\begin{array}{c}\mathrm{Gi} \\
4\end{array}$ & $\begin{array}{c}\text { ing ? } \\
5\end{array}$ & $\begin{array}{c}\text { Text } \\
6\end{array}$ & Cating & $\begin{array}{l}\text { of } \\
8\end{array}$ & $\begin{array}{c}\text { High } \\
9\end{array}$ & $\begin{array}{l}\text { Number of } \\
\text { Studeents } \\
\text { Rating } \\
\text { Text }\end{array}$ \\
\hline Gates et al. & 7.84 & & & & 2 & I & 8 & 16 & 19 & $3 \mathrm{I}$ & 77 \\
\hline Sorenson. & $7 \cdot 52$ & & & & 2 & 3 & 8 & 6 & 16 & I5 & 50 \\
\hline Pressey \& Rob & 7.25 & & & I & & 6 & I I & 9 & 26 & 8 & $6 I$ \\
\hline Crow \& Crow. & 7.24 & & I & & 3 & & $I$ & 13 & 9 & 7 & 34 \\
\hline Mursell... & 7.11 & & & I & 2 & Io & 9 & 15 & 21 & I 3 & 7 \\
\hline Skinner (Ed.) & 6.98 & & I & I & 2 & 2 & II & 14 & 15 & 7 & 53 \\
\hline Tuttle........ & 6.97 & & I & & & 4 & 2 & 13 & 6 & 4 & 30 \\
\hline Davi & 6.56 & & & 2 & 4 & 7 & 19 & II & 17 & 4 & 64 \\
\hline Woodruff. & 6.47 & 2 & & I & 2 & 8 & I3 & 13 & 15 & 3 & 57 \\
\hline Sny & 6.00 & & I & 4 & 6 & 7 & 9 & 3 & 7 & 6 & 43 \\
\hline $\mathbf{M c}$ & $4 \cdot 4 \mathrm{I}$ & 3 & 5 & 7 & 5 & ró & 4 & 4 & 2 & I & $4 \mathrm{I}$ \\
\hline Hilgard & 3.89 & 4 & 4 & Io & 5 & 5 & 4 & 3 & I & & 36 \\
\hline
\end{tabular}

TABLE 4

General Evaluation of Texts in Class $C$

\begin{tabular}{|c|c|c|c|c|c|c|c|c|c|c|c|}
\hline \multirow[b]{2}{*}{ Text } & \multirow{2}{*}{$\begin{array}{c}\text { Average } \\
\text { Rating }\end{array}$} & \multirow{2}{*}{ Low } & \multicolumn{3}{|c|}{ Number Givin } & \multicolumn{3}{|c|}{ Text Rating of } & \multirow[b]{2}{*}{8} & \multicolumn{2}{|c|}{$\begin{array}{l}\text { Number o } \\
\text { Students }\end{array}$} \\
\hline & & & 2 & 3 & 4 & 5 & 6 & 7 & & 9 & Text \\
\hline Sorenson. & 7.86 & & & I & I & 3 & 3 & 4 & 9 & 22 & 43 \\
\hline Crow \& $\mathrm{Cr}_{\mathrm{r}}$ & 7.25 & & & & $\mathbf{I}$ & 6 & 3 & 4 & 10 & 8 & 32 \\
\hline Skinner (Ed. & 7.13 & & & & $\mathbf{I}$ & 4 & 2 & 6 & 6 & 5 & 24 \\
\hline Gates et al. & 7.10 & & $\mathbf{I}$ & $\mathbf{I}$ & 3 & 3 & 4 & 7 & $I_{4}$ & 9 & 42 \\
\hline Pressey \& Robinson. & $6.8 \mathrm{I}$ & 2 & & & 2 & 4 & 2 & 6 & 10 & 6 & 32 \\
\hline Mursell. & 6.67 & & & 3 & 4 & 7 & 2 & 8 & 10 & 8 & 42 \\
\hline Woodruff. & 6.07 & 2 & I & I & 3 & 2 & 4 & 9 & 3 & 4 & 29 \\
\hline Tuttl & .5 .78 & & 3 & I & 2 & 3 & 4 & 5 & 3 & 2 & 23 \\
\hline Davis & .5 .77 & I & I & I & 4 & 7 & 5 & 4 & 5 & 2 & 30 \\
\hline & $.5 \cdot 35$ & I & 2 & & 4 & 4 & 3 & 2 & 2 & 2 & 20 \\
\hline$\&$ Com & 5.30 & 2 & & $\mathbf{I}$ & 7 & I & 4 & 5 & 2 & I & 23 \\
\hline Hilgard & 5.13 & 2 & I & 2 & I & 2 & I & 2 & 3 & I & 15 \\
\hline
\end{tabular}


Tables 3 and 4 give a more detailed picture of the results upon which Table 2 is based. Table 3 summarized general evaluation results for Classes $\mathrm{A}$ and $\mathrm{B}$. Table 4 does the same for Class $\mathrm{C}$ taught by the second instructor.

In general, when results on Table 3 are compared with results on Table 4 , we find a high degree of positive relationship. This would seem to indicate that, regardless of differing methods of the two instructors, the average ratings given individual books by students are very similar.

Of perhaps even greater significance for good teaching, we see on Tables 3 and 4 that individual students differ greatly in

TABLE 5

Evaluation of Texts Based on Help Received on Professional Problems by all Classes

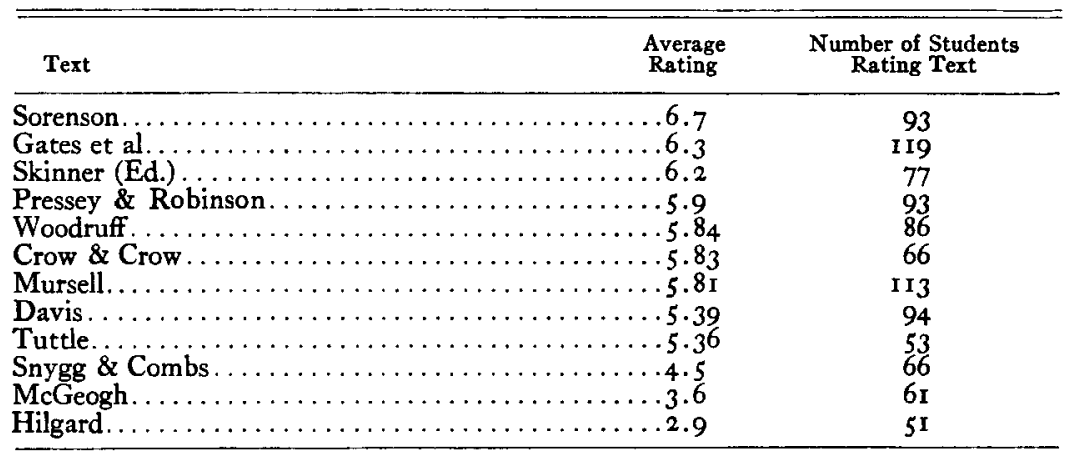

their reactions to the same book. For example, in Classes $\mathrm{A}$ and $B$ (Table 3) we note that while eighteen students rated Woodruff's book as excellent (Rating of 8 or 9), two students thought it extremely poor and gave it the lowest possible rating. These results make the common practice of having only one or two texts in a class appear to be a very questionable practice.

Table 5 gives a concise summary of results on the question: What is your rating of the book based on the actual help you got on the professional problems you attacked this term? It will be noted that the rank of individual books on this criterion is very similar to rank on the first question for which results were presented in Table 2. Sorenson and Gates remain on top and the last three books on each list are identical. 
TABLE 6

Evaluation of Help Received on Problems Attacked during Term in Classes $A$ and $B$

\begin{tabular}{|c|c|c|c|c|c|c|c|c|c|c|}
\hline $\begin{array}{c}\text { Average } \\
\text { Rating }\end{array}$ & $\begin{array}{c}\text { Low } \\
1\end{array}$ & $\begin{array}{l}N \\
2\end{array}$ & $\begin{array}{l}\mathrm{umb} \\
\mathbf{3}\end{array}$ & $\begin{array}{c}\text { Giv } \\
4\end{array}$ & $\begin{array}{c}\mathrm{ng} T \\
5\end{array}$ & $\begin{array}{c}x t R \\
6\end{array}$ & $\begin{array}{c}\text { ting } \\
7\end{array}$ & $\begin{array}{l}\text { of } \\
8\end{array}$ & $\underset{9}{\text { High }}$ & $\begin{array}{l}\text { Number of } \\
\text { Students } \\
\text { Rating } \\
\text { Text }\end{array}$ \\
\hline$\ldots 6.55$ & & 2 & 2 & 5 & 7 & 8 & 8 & I I & 10 & 53 \\
\hline Gates et al. & 3 & I & 3 & 6 & 7 & I I & 19 & I I & I6 & 77 \\
\hline Sorenson...... & 2 & I & 3 & 2 & 4 & 10 & 7 & 12 & 9 & 50 \\
\hline Crow \& Crow ......6.18 & 3 & I & I & 2 & 5 & 2 & 7 & 9 & 4 & 34 \\
\hline Pressey \& Robinson... 6.16 & 3 & 2 & 2 & I & 14 & 8 & II & I 6 & 4 & $6 \mathrm{I}$ \\
\hline Woodruff. . . . . . . 5.96 & & 2 & 5 & 7 & 9 & 12 & 8 & 6 & 8 & 57 \\
\hline$\ldots \ldots \ldots 5.85$ & 2 & 3 & 4 & 14 & 9 & II & 7 & IO & I I & 71 \\
\hline Tuttle........ 5.83 & & 3 & 3 & 3 & 3 & 7 & 3 & 2 & 6 & 30 \\
\hline Davis .......... 5.50 & 2 & 4 & 4 & I I & 8 & I 3 & I 2 & 6 & 4 & 64 \\
\hline Snygg \& Combs.... . 4.95 & 3 & 5 & 6 & 5 & 6 & 6 & 5 & 2 & 5 & 43 \\
\hline McGeogh......... 3.00 & I2 & IO & 5 & 3 & 7 & 2 & & I & I & $4 \mathrm{I}$ \\
\hline Hilgard.......... 2.78 & 14 & 7 & 4 & 4 & 3 & $\mathbf{I}$ & I & 2 & & 36 \\
\hline
\end{tabular}

TABLE 7

Evaluation of Help Received on Problems Attacked during Term in Class C

\begin{tabular}{|c|c|c|c|c|c|c|c|c|c|c|c|}
\hline \multirow[b]{2}{*}{ Text } & \multirow{2}{*}{$\begin{array}{c}\text { Average } \\
\text { Rating }\end{array}$} & \multirow{2}{*}{$\operatorname{Low}_{1}$} & \multicolumn{7}{|c|}{ Number Giving Text Rating of } & \multirow{2}{*}{$\underset{9}{\mathrm{High}}$} & \multirow{2}{*}{$\begin{array}{c}\text { Number of } \\
\text { Students } \\
\text { Rating } \\
\text { Text }\end{array}$} \\
\hline & & & 2 & 3 & 4 & 5 & 6 & 7 & 8 & & \\
\hline Sorenson. & $6.8_{4}$ & 2 & 2 & I & 3 & 2 & 5 & 7 & 5 & I6 & 43 \\
\hline Gates et al & 5.88 & 2 & I & 4 & 5 & $\overline{6}$ & 5 & 6 & 8 & 5 & $4^{2}$ \\
\hline Mursell... & $5 \cdot 74$ & 3 & 4 & I & 3 & 8 & 5 & 5 & 7 & 6 & 42 \\
\hline Woodruff. & 5.59 & 3 & & I & 6 & I & 3 & II & 4 & & 29 \\
\hline Pressey \& Robinson. & 5.53 & 3 & 3 & 2 & 3 & 5 & I & 5 & 6 & 4 & $3^{2}$ \\
\hline Crow \& Crow. & $5 \cdot 47$ & I & 3 & 2 & 4 & 7 & 4 & 4 & 4 & 3 & 32 \\
\hline Skinner (Ed. & 5.46 & I & 2 & 3 & 3 & 4 & 2 & I & 6 & 2 & 24 \\
\hline Davis. & 5.1 & 5 & 2 & I & 4 & 4 & I & 5 & 6 & 2 & 30 \\
\hline McGeogh. & 4.80 & 3 & 2 & I & 2 & 5 & I & 2 & 3 & I & 20 \\
\hline Tuttle... & 4.74 & 3 & 2 & 4 & & 3 & 5 & 4 & I & I & 23 \\
\hline Snygg \& Combs & 3.74 & 4 & 5 & 2 & 3 & 5 & 2 & & I & I & 23 \\
\hline Hilgard. & 3.27 & 6 & 2 & 2 & & 2 & I & & $\mathbf{I}$ & I & 15 \\
\hline
\end{tabular}

An analysis of the variance of ratings which produced the means given in Table 5 gives these results:

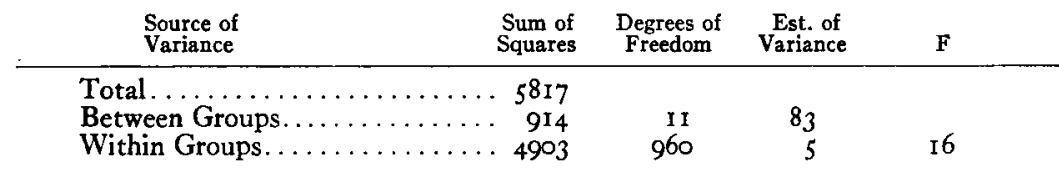

The $\mathrm{F}$ of $\mathrm{I} 6$ indicates the mean ratings for books differed very significantly since only an $\mathrm{F}$ of 2.26 is required for significance at the I per cent level.

Table 6 presents a detailed picture of ratings made by Classes $\mathrm{A}$ and $\mathrm{B}$ to the question given in the preceding paragraph. Table 7 does the same for Class $\mathrm{C}$. In comparing results on 
Table 6 with those on Table 8 we note that, with two exceptions, ranks for individual books do not differ by more than two positions. The exceptions are Skinner, which, with a top rank in Classes $A$ and $B$, has a rank of seven in Class $C$, and Mursell which, with a rank of seven in Classes $A$ and $B$, moves up to a rank of three in Class $C$. The cause for these two deviations from the general picture is not known. One possible cause may be found in the different methods used by the two instructors. The somewhat different composition of the two groups in terms of interest areas as shown in Table $I$ is another possible cause of the difference.

\section{Summary and Conclusions}

Graduate students in three advanced Educational Psychology classes rated textbooks on a nine-point scale. The ratings were made on the basis of two questions: (I) What is your general rating of the book as an aid in giving you a better understanding of problems and principles of educational psychology?; (2) What is your rating of the book based on the actual help you got on the professional problems you attacked?

I. The results present a clear-cut indication that a text which some students think is extremely valuable may be thought of by other students as practically useless, and strongly suggests that a "good" text for some students may be a "poor" text for other students.

2. On the basis of the single factor of student reactions to the texts much support is given for using Sorenson, Gates, Skinner, Crow and Crow, and Pressey and Robinson as texts. On the same basis, the texts by Mursell, Woodruff, Tuttle, and Davis seem to be of intermediate value. It appears that the instructors may have made a mistake in suggesting Snygg and Combs, McGeogh, and Hilgard for use by these classes.

3. Probable or actual learner reactions to a text should be one factor which should be considered in the selection of texts.

4. It is possible to get a systematic picture of learner reactions to texts through the procedure described here. 